\title{
Peningkatan Kemampuan Membuat Petunjuk Penggunaann Alat Peraga untuk Menentukan Luas Daerah Bangun Datar Kepada Guru SD di Kecamatan Labuapi
}

\author{
Ketut Sarjana ${ }^{*}{ }^{*}$ Muhammad Turmuzi ${ }^{1}$, Nani Kurniati ${ }^{1}$, Nurul Hikmah ${ }^{1}$, Ratna Yulis Tyaningsih ${ }^{1}$ \\ ${ }^{1}$ Pendidikan MIPA, Fakultas Keguruan dan Ilmu Pendidikan, Universitas Mataram, Indonesia
}

DOI: https:// doi.org/10.29303/ujcs.v2i1.23

\section{Article Info}

Received: February 2th 2021

Revised: March 6th, 2021

Accepted: March 9'th, 2021

ABSTRAK: Para guru Sekolah Dasar (SD) di gugus II Labuapi belum pernah membuat petunjuk penggunaan alat peraga. Jangankan petunjuk penggunaan, alat peraganya saja belum pernah dibuat. Pengetahuan mengenai pembuatan alat peraga berikut petunjukkannya sangat kurang didapatkan dan kesempatan untuk mempelajari juga sedikit. Tujuan yang ingin dicapai dalam kegiatan pengabdian ini adalah: (1) Meningkatkan pengetahuan para guru SD Gugus II di Kecamatan Labuapi tentang konsep luas daerah dan prinsip luas daerah dapat dibagun melalui konsep kekekalan luas; (2) Meningkatkan keterampilan membuat petunjuk pengunaan alat peraga untuk menetukan luas daerah bangun data. Kegiatan pengabdian dilakukan melalui pendalaman tentang konsep dan prinsip luas daerah utamanya parameter penentu luas daerah dengan cara presentasi, demonstrasi, simulasi dan praktek merancang media peraga prinsip luas, dan diskusi dalam kelompok kerja dan presentasi tentang media dan pedoman yang telah dirancang dan demontrasi cara penggunaaannya. Hasil pelatihan sangat efektif, ini ditunjukkan adanya perbedaan rata-rata yang signifikan antara hasil pretes dan post-tes. Kegiatan Pengabdian pada Masyarakat yang telah dilakukan ternyata sangat efektif yakni terjadi perubahan kearah perbaikan yang signifikan. Hal ini dapat ditunjukkan dengan adanya perbedaan rerata pre-tes sebesar 4,08 dengan rata-rata pos-tes sebesar 7,35. Hasil uji $t$ menunjukkan bahwa $\left[t_{\mathrm{h}}\left[=15,286>t_{\text {tab }}=2,03\right.\right.$ pada taraf signifikasi 5 $\%$. Ini berarti pula bahwa pengetahuan tentang luas daerah bangun datar dan keterampilan merancang media dan pedoman operasionalnya para guru di Gugus II Kecamatan Labuapi meningkat secara meyakinkan yang ditunjukkan oleh perubahan rerata tersebut.

Kata kunci: Petunjuk penggunaan; Alat peraga; Luas daerah.

Abstract: Elementary school teachers in labuapi group II have never made instructions for the use of props. Do not use instructions, props alone have never been made. Knowledge of the manufacture of props and instructions are very poorly obtained and the opportunity to learn is also minimal. The objectives to be achieved in this devotional activity are: (1) Improving the knowledge of the teachers of SD Cluster II in Labuapi Subdistrict about the concept of area area and the principle of area area can be built through the concept of broad immortality; (2) Improve the skill of making instructions for using props to determine the area of data building. Devotion activities are carried out through the deepening of the concepts and principles of the area, especially the parameters of determining the area by means of presentation, demonstration, simulation and practice of designing a broad principle model media, and discussions in working groups and presentations about the media and guidelines that have been designed and demontrasi how it is used. The training results are very effective, this is shown to be a significant average difference between pretest and post-test results. Community Service activities that have been conducted turned out to be very effective, namely a change towards significant improvement. This can be shown by the difference in the pre-test average of 4.08 with a post-test average of 7.35 . The test result $\mathrm{t}$ shows that $=15,286>\mathrm{ttab}=2.03$ at the signification level of $5 \%$. This also means that knowledge of the area of flat build area and the skills of designing media and operational guidelines of teachers in Cluster II Labuapi Subdistrict increased convincingly as shown by the average change.

Keywords: Instructions for use; props; area.

Citation: $\quad$ Sarjana, K., Turmuzi, M., Kurniati, N., Hikmah, N., \& Tyaningsih, R. (2021). Peningkatan Kemampuan Membuat Petunjuk Penggunaann Alat Peraga Menentukan Luas Daerah Bangun Datar Kepada Para Guru SD Di Kecamatan Labuapi. Unram Journal of Community Service, 2(1), 12-16. doi:https:// doi.org/10.29303/ujcs.v2i1.23

\footnotetext{
*Email: kssarjanafkip@gmail.com
} 


\section{Pendahuluan}

Siswa sekolah dasar dalam belajar materi geometri cukup sulit, seperti terungkap hasil survei Program for international Student Asseement 2000/2001 menyatakan bahwa siswa lemah dalam geometri khususnya dalam ruang dan bentuk (Sarjana et al., 2020). Hal ini disebabkan oleh karena geometri bersifat abstrak sedangkan siswa sekolah dasar cara berpikirnya masih pada taraf operasi kongkret. Siswa sekolah dasar berpikirnya masih pada taraf operasi kongkret (Prabowo \& Widodo, 2018).

Berkenaan dengan hal ini jika siswa sekolah dasar belajar konsep atau prinsip geometri sebaiknya dihadapkan dengan obyek atau benda yang kongkrit yang cocok. Selanjutnya obyek kongkrit ini dimanipulasi oleh anak untuk membangun konsep atau prinsip geometri yang sedang dipelajari. Dalam proses belajar anak sebaiknya diberi kesempatan memanipulasi benda-benda yang dirancang secara khusus dan dapat diotak atik oleh siswa di dalam memahami konsep matematika (Sugiarto et al., 2012).

Pembelajaran geometri yang abstrak jika disajikan dalam bentuk kongkret, siswa akan merasakan lebih mudah memahami dan mengerti konsep yang sedang dipelajari. Hal ini sejalan dengan yang diungkap Russeffendi dalam (Sarjana et al., 2018) yang berbunyi saya dengar dan saya lupa, saya lihat dan saya tahu, saya berbuat maka saya mengerti. Disamping itu, belajar matematika adalah proses membangun konsep-konsep dan prinsip-prinsip matematika tidak sekedar menyodorkan yang terkesan pasip dan statis, namun belajar itu harus aktif dan dinamis (Siagian, 2017; Sarjana et al., 2018). Akibatnya pembelajaran geometri yang abstrak mengharuskan untuk memanfaatkan media. Hal ini sesuai dengan pandangan kontruktivis yang menyatakan bahwa didalam belajar dan mengajar dimana peserta didik harus membangun sendiri arti dari pengalamannya dan interaksi dengan orang lain (Sugrah, 2020).

Media yang digunakan siswa atau guru dengan baik dapat mempengaruhi efektifitas proses belajar dan mengajar (Dwijayani, 2019). Hal ini merupakan nslah satu contoh kajian yang menunjukan bahwa penggunaan alat peraga dalam pembelajaran matematika menyebabkan pempelajaran menjadi efektif (Murdiyanto \& Mahatama, 2014; Sudarwanto \& Hadi, 2014). Namun pernyataan itu belum tegas mengatakan bagaimana caranya menggunakan media itu supaya imformasi tepat sampai dan tidak berbeda untuk kelas berbeda.

Pada kenyataannya para guru sekolah dasar jika menggunakan alat peraga dalam pembelajaran geometri hasilnya berbeda satu dengan yang lainnya walaupun alat peraga yang digunakan sama untuk materi yang sama dan pada tingkatan yang sama. Ini berarti bahwa para guru yang mengajar geometri dengan menggunakan alat peraga yang sama membutuhkan instrumen lain supaya pesan yang disampaikan sama. Itulah sebabnya diperlukan suatu petunjuk penggunaan alat peraga. Adanya petunjuk ini membuat alat peraga menjadi konsisten dalam fungsinya yakni pembelajaran menjadi efektif.

Penelitian telah dilakukan oleh Sarjana et al., (2020) mengenai desain Alat peraga Geometri dan petunjuk penggunaannya menyimpulkan bahwa alat peraga dan pedoman operasionalnya sangat valid. Itulah sebabnya hasil ini perlu di sosialisasikan kepada para guru Sekolah Dasar. Disisi lain hasil wawancara guru menunjukkan bahwa guru belum pernah membuat petunjuk penggunaan alat peraga, bahkan banyak guru belum pernah membuat alat peraga itu sendiri. Pengetahuan mengenai pembuatan alat peraga dengan petunjuknya sangat kurang didapatkan dan sedikit kesempatan untuk mempelajarinya. Alat peraga lengkap dengan petunjuknya merupkan media untuk mengatasi persoalan pembelajaran geometri (Sarjana et al., 2018).

Alat peraga dipandang sebagai benda nyata untuk membangun konsep maupun prinsip yang berkaitan dengan geometri. Sedangkan petunjuk penggunaan memberikan informasi tentang penggunaan alat tersebut agar terhindar dari kesalahan. Observasi terhadap perilaku orang lain seseorang membentuk pengertian bagaiman melakukan tingkah laku baru, dan pada kesempatan berikutnya informasi yang telah dikodekan tersebut berfungsi sebagai suatu pemandu untuk tindakan (Sarjana et al., 2018; Sarjana et al., 2020).

Dari uraian di atas masalah yang muncul adalah para guru gugus II di Kecamatan Labuapi pengetahuan dan keterampilannya untuk merancang petunjuk penggunaan alat peraga dalam pembelajaran menentukan luas daerah bangun datar masih rendah. Tujuan yang ingin dicapai dalam kegiatan pengabdian ini adalah: (1) Meningkatkan pengetahuan para guru SD Gugus II di Kecamatan Labuapi tentang konsep luas daerah dan prinsip luas daerah dapat dibagun melalui konsep kekekalan luas; (2) Meningkatkan keterampilan membuat petunjuk pengunaan alat peraga untuk menetukan luas daerah bangun data.

\section{Metode Pelaksanaan}

Tujuan dari kegiatan pengabdian ini adalah meningkatkan pengetahuan dan keterampilan merancang petunjuk penggunaan alat tentang menentukan luas daerah. Beberapa kegiitan harus dilakukan untuk mencapai tujuan kegiatan ini:

1. Memberikan pendalaman materi. 
Sebelum pendalaman materi para guru diberikan pre-test yang berisikan tentang pengertian luas daerah, konsep kekelan luas dan hubungan antara bangun datar. Dari hubungan itu dapat dibentuk bangunbangun lain berdasarkan bangun daerah persegi panjang. Seperti halnya bangun Jajaran genjang, Segitiga, trapezium, layang-layang, daerah lingkaran dapat dibentuk melalui pendekatan daerah persegi panjang. Pendalaman materi disini dimulai dari pembahasan luas daerah, dan menyampaikan cara-cara mengkontruksi medianya melalui pendekatan tertentu.

2. Praktek dan simulasi.

Pada kegiatan praktek disini para guru membuat daerah bangun datar, seperti daerah persegi panjang, jajaran genjang, segitiga, trapezium, layanglayang, belah ketupat dan daerah lingkaran dari karton atau kertas manila yang telah disiapkan. Selanjutnya daerah bangun datar yang dibuat dipotong-potong menjadi beberapa daerah tertentu. Selanjutnya simulasi membuat potongan yang terjadi dirangkai menjadi daerah persegi panjang. Karena menentukan rumus luas daerah didekati dari luas darah persegi panjang dan hukum kekekalan luas. Hasil simulasi ditempelkan pada stereoform yang telah disediakan. Selanjutnya didemonstrasikan salah satu alat peraga yang telah dibuat.

Dari rancangan yang sudah disepakati dibuatkan petunjuk penggunaannya. Petunjuk ini berisikan tentang langkah-langkah pengunaan alat.
Penggunaan alat dimulai dari menggali prasyarat, merangkai bangun datar, membuat perhitungan dan membuat hubungan antara besaran yang diperoleh dan membuat kesimpulan.

3. Diskusi dan Presentasi.

Peserta pengabdian dibagi menjadi 5 kelompok kerja. Tiap kelompok mengerjakan tugas yang berbeda. Hasil pekerjaan didiskusikan dan disimulasikan pada tiap kelompok. Pekerjaan menyangkut tentang merancang alat peraga dan petunjuknya. Selanjutnya pekerjaan tiap kelompok dipresentasikan pada kelompok besar untuk mendaptkan tanggapan dari peserta kelompok yang lain dan penegasan dari tim pengabdian.

4. Untuk menguji efektivitas dari kegiatan yang dilakukan digunakan uji $\mathrm{t}$ (Anton dayan, 1996) dua arah dan membandingan setiap daya serap tiap persoalan.

\section{Hasil dan Pembahasan}

\section{Hasil Pengabdian Pada masyarakat.}

Sebelum dilakukan pelatihan peserta diberikan pretes yang terdiri dari pengetahuan tentang tentang unsur unsur dari bangu datar, luas daerah dan keterampilan menyusun kalimat pedoman operasional yang disesuaikan dengan alat peraganya. Mengenai hasil tes dapat dilihat pada table berikut:

Tabel 1. Hasil Pre Tes peserta Pengabdian pada masyarakat.

\begin{tabular}{|c|c|c|c|c|c|c|c|c|c|c|c|}
\hline \multirow{2}{*}{ Nama Peserta } & Kunci & $\mathrm{d}$ & $\mathrm{d}$ & $\mathrm{d}$ & $\mathrm{d}$ & $\mathrm{d}$ & $\mathrm{d}$ & $\mathrm{d}$ & $\mathrm{d}$ & $\mathrm{d}$ & $\mathrm{d}$ \\
\hline & Skor Pretes & 1 & 2 & 3 & 4 & 5 & 6 & 7 & 8 & 9 & 10 \\
\hline Siti Aisyah & 5 & $\mathrm{a}$ & c & $\mathrm{d}$ & $\mathrm{d}$ & $\mathrm{b}$ & a & $\mathrm{d}$ & $\mathrm{b}$ & $\mathrm{d}$ & $\mathrm{d}$ \\
\hline Nyoman Ayu Kartini & 5 & a & c & d & $\mathrm{d}$ & a & $\mathrm{d}$ & $d$ & a & $\mathrm{d}$ & a \\
\hline Sumarni & 4 & $\mathrm{~b}$ & c & d & $\mathrm{d}$ & a & a & a & a & $\mathrm{d}$ & $\mathrm{d}$ \\
\hline Hj.Sumiatun & 5 & $\mathrm{~b}$ & $\mathrm{~d}$ & d & $\mathrm{d}$ & a & a & d & c & c & d \\
\hline Siti Zuhriyatul N & 2 & $\mathrm{~b}$ & c & a & c & $b$ & $\mathrm{a}$ & a & a & $\mathrm{d}$ & d \\
\hline Siti janibah & 5 & d & a & a & d & a & d & d & $\mathrm{b}$ & d & a \\
\hline Rosmiana & 4 & c & $\mathrm{b}$ & d & d & d & $\mathrm{b}$ & c & $\mathrm{d}$ & a & $\mathrm{b}$ \\
\hline Hj. Maesarah & 5 & $\mathrm{~d}$ & $\mathrm{~d}$ & a & $\mathrm{d}$ & d & a & c & $\mathrm{b}$ & $\mathrm{d}$ & c \\
\hline Baiq Yusriana Herdiana & 2 & $\mathrm{~d}$ & $c$ & a & a & $d$ & $b$ & c & c & c & $b$ \\
\hline Siti Halimatussakdiah & 5 & $\mathrm{~d}$ & $\mathrm{~b}$ & d & $\mathrm{d}$ & d & a & d & c & a & a \\
\hline Siti Munawarah & 3 & $\mathrm{~d}$ & a & $\mathrm{d}$ & a & a & $b$ & $\mathrm{~b}$ & $\mathrm{~d}$ & $\mathrm{~b}$ & $\mathrm{a}$ \\
\hline Rahmat Hamdani S & 4 & a & c & d & a & d & d & a & $\mathrm{b}$ & c & d \\
\hline Eli Susanti & 4 & $\mathrm{~b}$ & c & d & c & d & a & d & a & d & $\mathrm{b}$ \\
\hline Parman & 5 & $\mathrm{~b}$ & $\mathrm{~d}$ & d & c & d & d & c & $\mathrm{b}$ & d & c \\
\hline Made Ruci & 2 & a & $\mathrm{b}$ & a & c & a & $\mathrm{d}$ & a & $\mathrm{d}$ & $\mathrm{s}$ & $\mathrm{b}$ \\
\hline Sarafuddin,S.Pd & 4 & $b$ & c & d & c & $d$ & a & $d$ & a & $\mathrm{d}$ & a \\
\hline Faesal Saleh & 5 & $\mathrm{~d}$ & $\mathrm{~b}$ & d & c & d & $\mathrm{b}$ & c & $\mathrm{b}$ & $\mathrm{d}$ & $\mathrm{d}$ \\
\hline Suparman & 2 & a & $\mathrm{b}$ & a & d & a & d & a & a & c & $\mathrm{b}$ \\
\hline Saeful Bahri & 3 & a & $\mathrm{d}$ & c & a & d & $b$ & $b$ & $\mathrm{~b}$ & $b$ & d \\
\hline I Gede Mardana & 4 & $\mathrm{~b}$ & c & d & a & d & $\mathrm{b}$ & d & $\mathrm{b}$ & d & c \\
\hline Mursahid & 4 & d & $\mathrm{d}$ & a & c & a & $\mathrm{b}$ & a & $\mathrm{d}$ & d & c \\
\hline Fatmah Saleh & 4 & $\mathrm{~b}$ & $\mathrm{~b}$ & d & a & a & $\mathrm{d}$ & d & c & $\mathrm{d}$ & $b$ \\
\hline Miskiah & 4 & $b$ & $\mathrm{~d}$ & a & c & d & $b$ & a & $\mathrm{d}$ & $\mathrm{d}$ & c \\
\hline Ernaningsih & 4 & $\mathrm{~b}$ & $\mathrm{~b}$ & c & a & a & $\mathrm{d}$ & $\mathrm{d}$ & c & $\mathrm{d}$ & d \\
\hline
\end{tabular}




\begin{tabular}{|c|c|c|c|c|c|c|c|c|c|c|c|}
\hline \multirow{2}{*}{ Nama Peserta } & Kunci & $\mathrm{d}$ & $\mathrm{d}$ & $\mathrm{d}$ & $\mathrm{d}$ & $\mathrm{d}$ & $\mathrm{d}$ & $\mathrm{d}$ & $\mathrm{d}$ & $\mathrm{d}$ & $\mathrm{d}$ \\
\hline & Skor Pretes & 1 & 2 & 3 & 4 & 5 & 6 & 7 & 8 & 9 & 10 \\
\hline Heryani, S.Pd & 3 & $\mathrm{~d}$ & $\mathrm{~b}$ & $\mathrm{a}$ & $\mathrm{b}$ & $\mathrm{a}$ & $\mathrm{b}$ & $\mathrm{a}$ & $\mathrm{d}$ & c & $\mathrm{d}$ \\
\hline Ni Luh Arsani & 4 & $\mathrm{~b}$ & $\mathrm{~b}$ & $\mathrm{c}$ & a & $\mathrm{a}$ & $\mathrm{d}$ & $\mathrm{d}$ & c & $\mathrm{d}$ & d \\
\hline Total benar & & 8 & 6 & 14 & 9 & 10 & 9 & 11 & 5 & 16 & 9 \\
\hline Daya serap & & 30,8 & 23,1 & 53,8 & 34,6 & 38,5 & 34,6 & 42,3 & 19,3 & 38,9 & 34,6 \\
\hline
\end{tabular}

Setelah diadakan pelatihan peserta diberikan postes. Mengenai hasil penilaian tersebut tertuang pada tabel berikut.

Tabel 2. Hasil Pos tes Peserta pengabdian pada masyarakat.

\begin{tabular}{|c|c|c|c|c|c|c|c|c|c|c|c|c|}
\hline \multirow{2}{*}{ Nama Peserta } & \multicolumn{2}{|l|}{ Skor } & $\mathrm{d}$ & $\mathrm{d}$ & $\mathrm{d}$ & $\mathrm{d}$ & $\mathrm{d}$ & $\mathrm{d}$ & $\mathrm{d}$ & $\mathrm{d}$ & $\mathrm{d}$ & $\mathrm{d}$ \\
\hline & Pretes & Postes & 1 & 2 & 3 & 4 & 5 & 6 & 7 & 8 & 9 & 10 \\
\hline Siti Aisyah & 5 & 7 & $\mathrm{~d}$ & $\mathrm{~b}$ & $\mathrm{~d}$ & $\mathrm{~d}$ & $\mathrm{~d}$ & $\mathrm{a}$ & $\mathrm{b}$ & $\mathrm{d}$ & $\mathrm{d}$ & $\mathrm{d}$ \\
\hline Nyoman Ayu Kartini & 5 & 8 & $\mathrm{~b}$ & d & d & $\mathrm{d}$ & d & d & $\mathrm{b}$ & d & d & d \\
\hline Sumarni & 4 & 8 & $\mathrm{~d}$ & $\mathrm{~b}$ & $\mathrm{~d}$ & $\mathrm{~d}$ & $\mathrm{~d}$ & $\mathrm{~d}$ & $\mathrm{~d}$ & $\mathrm{~b}$ & $\mathrm{~d}$ & $\mathrm{~d}$ \\
\hline Hj.Sumiatun & 5 & 7 & $\mathrm{~d}$ & $\mathrm{~b}$ & $\mathrm{~d}$ & $\mathrm{~d}$ & a & $\mathrm{d}$ & $\mathrm{b}$ & $\mathrm{d}$ & $\mathrm{d}$ & $\mathrm{d}$ \\
\hline Siti Zuhriyatul N & 2 & 6 & $\mathrm{~b}$ & d & d & $\mathrm{d}$ & $\mathrm{b}$ & d & d & d & b & a \\
\hline Siti janibah & 5 & 7 & $\mathrm{~d}$ & d & a & $\mathrm{d}$ & a & $\mathrm{d}$ & d & d & d & c \\
\hline Rosmiana & 4 & 7 & c & d & $\mathrm{d}$ & $\mathrm{d}$ & d & $\mathrm{b}$ & d & $\mathrm{b}$ & d & d \\
\hline Hj. Maesarah & 5 & 8 & $\mathrm{~d}$ & $\mathrm{~d}$ & $\mathrm{~d}$ & $\mathrm{~d}$ & a & $\mathrm{b}$ & $\mathrm{d}$ & $\mathrm{d}$ & $\mathrm{d}$ & $\mathrm{d}$ \\
\hline Baiq Yusriana Herdiana & 4 & 7 & $\mathrm{~d}$ & $\mathrm{~b}$ & $\mathrm{~d}$ & $\mathrm{~d}$ & d & $\mathrm{b}$ & d & d & d & $\mathrm{a}$ \\
\hline Siti Halimatussakdiah & 5 & 8 & $\mathrm{~d}$ & d & $\mathrm{d}$ & $\mathrm{d}$ & d & a & d & $\mathrm{d}$ & $\mathrm{d}$ & $\mathrm{d}$ \\
\hline Siti Munawarah & 3 & 6 & d & d & a & $\mathrm{a}$ & d & $\mathrm{b}$ & d & $\mathrm{b}$ & $\mathrm{b}$ & d \\
\hline Rahmat Hamdani S & 4 & 7 & d & d & $\mathrm{d}$ & $\mathrm{d}$ & B & a & d & $\mathrm{b}$ & d & d \\
\hline Eli Susanti & 4 & 8 & $\mathrm{~d}$ & d & $\mathrm{d}$ & $\mathrm{d}$ & a & $\mathrm{d}$ & d & a & d & $\mathrm{d}$ \\
\hline Parman & 5 & 8 & $\mathrm{~b}$ & d & d & $\mathrm{d}$ & d & d & d & $\mathrm{b}$ & d & d \\
\hline Made Ruci & 4 & 7 & d & $\mathrm{b}$ & $\mathrm{d}$ & $\mathrm{d}$ & d & a & d & $\mathrm{b}$ & d & d \\
\hline Sarafuddin,S.Pd & 4 & 6 & d & a & $\mathrm{d}$ & $\mathrm{b}$ & d & $\mathrm{b}$ & d & $\mathrm{d}$ & d & c \\
\hline Faesal Saleh & 5 & 7 & $\mathrm{~d}$ & a & d & b & d & $\mathrm{b}$ & d & d & d & d \\
\hline Suparman & 3 & 7 & c & d & d & $\mathrm{d}$ & d & d & d & $\mathrm{b}$ & d & a \\
\hline Saeful Bahri & 3 & 8 & d & d & $\mathrm{d}$ & $\mathrm{d}$ & a & $\mathrm{b}$ & d & $\mathrm{d}$ & d & d \\
\hline I Gede Mardana & 4 & 8 & $\mathrm{~b}$ & d & $\mathrm{d}$ & $\mathrm{d}$ & d & $\mathrm{b}$ & d & d & d & d \\
\hline Mursahid & 4 & 7 & d & $\mathrm{b}$ & d & $\mathrm{d}$ & a & d & d & $\mathrm{b}$ & d & d \\
\hline Fatmah Saleh & 4 & 8 & $\mathrm{~d}$ & d & $\mathrm{b}$ & $\mathrm{d}$ & $\mathrm{b}$ & $\mathrm{d}$ & d & $\mathrm{d}$ & d & d \\
\hline Miskiah & 4 & 8 & $\mathrm{~d}$ & d & a & b & d & d & d & d & d & d \\
\hline Ernaningsih & 4 & 7 & $\mathrm{~d}$ & d & a & $\mathrm{d}$ & $\mathrm{b}$ & d & d & $\mathrm{d}$ & d & $\mathrm{b}$ \\
\hline Heryani, S.Pd & 3 & 7 & b & d & d & $\mathrm{d}$ & d & $\mathrm{b}$ & d & $\mathrm{b}$ & d & d \\
\hline Ni Luh Arsani & 4 & 9 & $\mathrm{~d}$ & $\mathrm{~d}$ & $\mathrm{~d}$ & d & $\mathrm{d}$ & $\mathrm{d}$ & $\mathrm{d}$ & $\mathrm{d}$ & $\mathrm{d}$ & c \\
\hline Total Benar Post tes & & & 18 & 17 & 21 & 22 & 16 & 13 & 19 & 16 & 21 & 19 \\
\hline Daya Serap post tes & & & 69,23 & 65,38 & 80.76 & 84,6 & 61,53 & 61,5 & 73,1 & 61,53 & 80,76 & 73,1 \\
\hline
\end{tabular}

Hasil uji t perbedaan rata-rata postes dan pretes tesaji pada table berikut.

Tabel 3. Hasil Uji t perbedaan rata-rata Pre tes dan

Postes.

\begin{tabular}{lccll}
\hline $\begin{array}{l}\text { Hasil pretest } \\
\text { postest }\end{array}$ & $\mathrm{N}$ & Mean & $\begin{array}{l}\text { Std. } \\
\text { Deviation }\end{array}$ & $\begin{array}{l}\text { Std. Error } \\
\text { Mean }\end{array}$ \\
\hline Nilai pretest & 26 & 4,08 & 0,796 & 0,156 \\
Nilai Posttest & 26 & 7,35 & 0,745 & 0,146 \\
\hline
\end{tabular}

Tabel 4: Hasil Uji-t untuk Kesetaraan

\begin{tabular}{|c|c|c|c|}
\hline Pengujian & $t$ & $\mathrm{df}$ & Sig. (2-tailed) \\
\hline $\begin{array}{l}\text { Equal variances } \\
\text { assumed }\end{array}$ & $-15,286$ & 50 & 0,000 \\
\hline $\begin{array}{l}\text { Equal variances not } \\
\text { assumed }\end{array}$ & $-15,286$ & 49,783 & 0,000 \\
\hline
\end{tabular}

\section{Pembahasan.}

Pendalaman materi.

Sebelum pendalaman materi para guru diberikan pre-test yang berisikan tentang pengertian luas daerah dan bagaimana mengaktualisasikan kedalam daerah persegi panjang, jajaran genjang, segitiga, trapezium, layamg-layang, daerah ling-karan. Pendalaman materi disini dimulai dari pembahasan luas daerah, menyampaikan cara-cara mengkontruksi medianya melalui pendekatan luas daerah persegi panjang. Pemberian tes ini dimaksudkan untuk memperoleh pengetahuan dan terampilan awal yang dimiliki oleh para guru. 


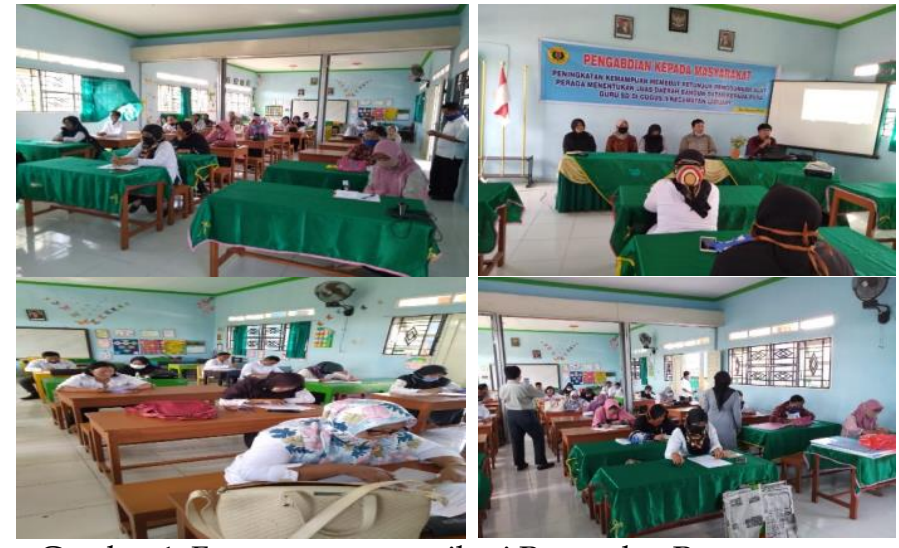

Gambar 1: Foto peserta mengikuti Pretes dan Post tes serta Pendalaman Materi

\section{Praktek dan simulasi.}

Pada kegiatan praktek disini para guru membuat daerah bangun datar dari karton atau kertas manila yang telah disiapkan. Para peserta disebar ke dalam 5 kelompok kerja yang masing-masing bekerja menentukan rumus luas daerah. Ada 5 daerah bangun datar yang dimaksud adalah, jajaran genjang, segitiga, trapesium, layang-layang, dan daerah lingkaran yang akan dicari rumus luasnya. Selanjutnya peserta melakukan simulasi memotong daerah bangun datar menjadi beberapa potongan daerah tertentu. Selanjutnya potongan-potongan yang terjadi dirangkai menjadi daerah persegi panjang. Dilanjutkan membuat pedoman operasional sesuai dengan alat yang telah dikontruksi.

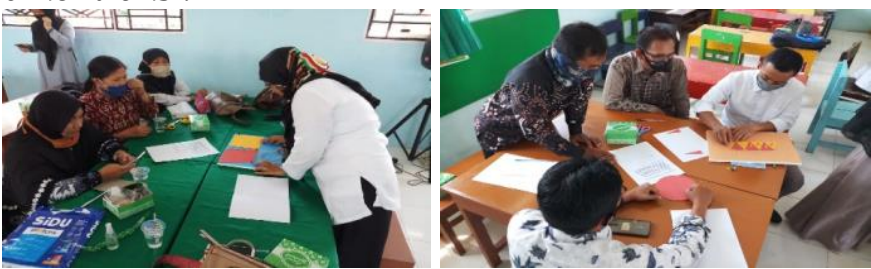

Gambar 2: Kegiatan Peserta Praktek merancang alat bahan
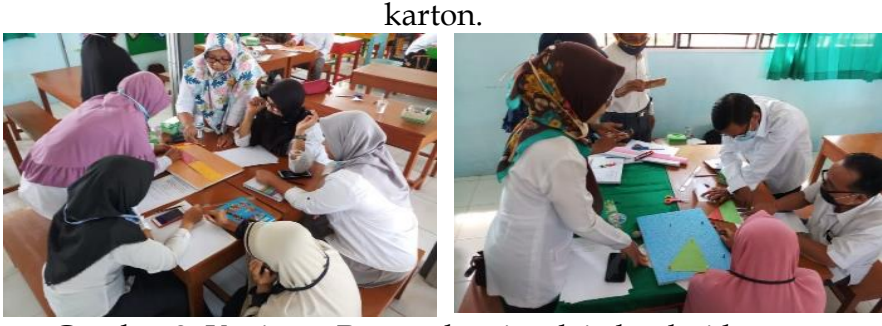

Gambar 3: Kegiatan Peserta bersimulai alat dari karton

\section{Diskusi dan presentasi.}

Peserta pelatihan dibagi menjadi 5 kelompok kerja. Setiap kelompok mendapatkan tugas sesuai dengan 5 topik bahasan yaitu mengkontruksi petunjuk penggunaan alat peraga bangun datar Jajaran genjang, Segitiga, Trapesium, Layang-layang dan Luas daerah Lingkaran. Di dalam kelompok peserta berdiskusi, merancang pedoman operasional dan menuliskan kalimat yang tepat disesuaikan alat peraga yang dikontruksi. Pedoman operasional menyangkut tentang langkah-langkah pengunaan alat. Penggunaan alat dimulai dari menggali prasyarat, merangkai bangun datar, membuat perhitungan dan membuat hubungan antara besaran yang diperoleh dan membuat kesimpulan. Hasil diskusi dipresentasikan dengan cara menempel pada stereoform yang telah disediakan, sedangkan untuk pedoman operasional dibahas setiap langkah penggunaaan media. Selanjutnya pekerjaan tiap kelompok dipresentasikan pada kelompok besar untuk mendaptkan tanggapan dari peserta kelompok yang lain dan penegasan dari tim pengabdian.
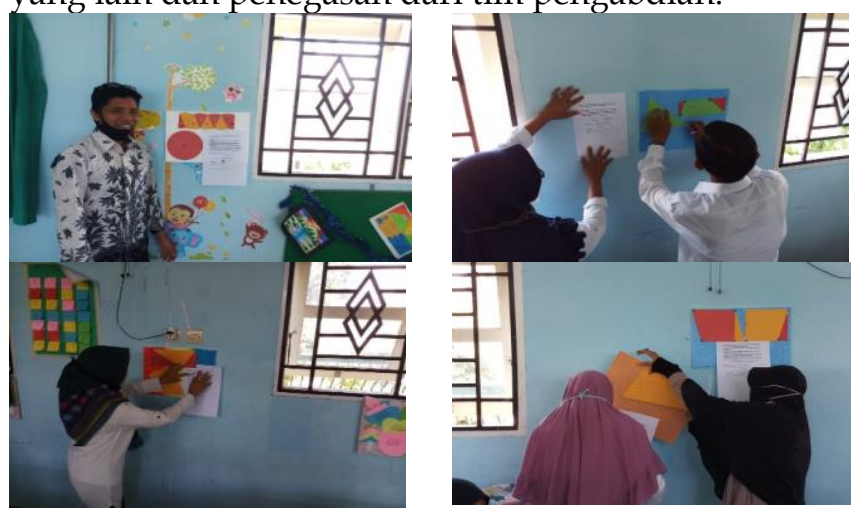

Gambar 4: Kegiatan Diskusi dan Presentasi

Para guru mengikuti sangat antausia dan serius, ditunjukkan dengan adanya tanya jawab dalam diskusi, bekerja dalam kelompok. Kemudian presentasi kelompok dan tukar pandangan secara klasikal sampai akhir kegiatan yang ditunjukan pula melalui rekaman dokumentasi. Setelah kegiatan pengabdian dilakukan para peserta diberikan postes.

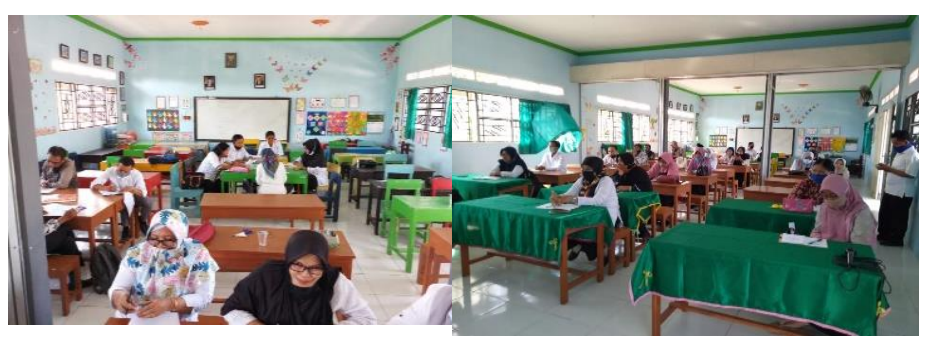

Gambar 5: Kegiatan Penguatan secara Klasikal

Hasil pelatihan sangat efektif, ini ditunjukkan adanya perbedaan rata-rata yang signifikan antara hasil pretes dan post-tes. Rata-rata hasil pretes sebesar 4,08 dan rata-rata postes sebesar 7,35. Hasil uji $t$ menunjukkan bahwa $\left|t_{\hat{k}}\right|=15,286>t_{\text {tab }}=2,03$. Besaran ini memperlihatkan bahwa nilai rata-rata yang diperoleh berbeda sangat meyakinkan pada taraf signifikansi 5\%. Disisi lain daya serap tiap persoalan meningkat secara tajam dari pretes dan postes. Hal ini ditunjukkan perbedaan prosentase daya serap pada soal pre-tes dan post-tes. 
Soal-soal yang dirancang mengilustrsikan persoalan menggali prasyarat pengetahuan tentang bangun datar yang diungkapkan pada soal - soal yang bernomor ganjil dan soal-soal yang bernomor genap mengungkap tentang bagaimana alat itu dikontruksi sampai kepada terbuat pedoman operasionalnya. Hal ini dapat dilihat seperti pada table 1 dan table 2. Pada kesempatan yang sama berarti telah terjadi perubahan yang signifikan kearah perbaikan tentang keterampilan para guru SD Gugus II di Kecamatan Labuapi setelah mengikuti kegiatan pengabdian ini.

\section{Kesimpulan}

Kegiatan Pengabdian pada Masyarakat yang telah dilakukan ternyata sangat efektif yakni terjadi perubahan kearah perbaikan yang signifikan. Hal ini dapat ditunjukkan dengan adanya perbedaan rerata pre-tes sebesar 4,08 dengan rata-rata pos-tes sebesar 7,35 . Hasil uji $t$ menunjukkan bahwa $\left\|t_{t_{h}}\right\|=15,286>t_{\text {tab }}$ $=2,03$ pada taraf signifikasi $5 \%$. Ini berarti pula bahwa pengetahuan tentang luas daerah bangun datar dan keteram-pilan merancang media dan pedoman operasionalnya para guru di Gugus II Kecamatan Labuapi meningkat secara meyakinkan yang ditunjukkan oleh perubahan rerata tersebut. Dengan diperolehnya hasil dalampengabdianini Bagi para guru SD yang menggunakan alat peraga ini, sebaiknya memiliki pengetahuan yang mendalam tentang materi yang akan diajarkan. Materi yang dimaksud meyangkut tentang istilah geometri yang benar dan konsep geometri yang benar shg mudah menggali prasyratnya.

\section{Ucapan Terimakasih}

Ucapan termakasih kepada Universitas Mataram telah memberikan dukungan pendanaan dari dana DIPA BLU UNRAM dengan kontrak No. 1979/UN18/LPPM/2020

\section{Daftar Pustaka}

Dwijayani, N. M. (2019). Development of circle learning media to improve student learning outcomes. Journal of Physics: Conference Series, 1321(2), 171187. https://doi.org/10.1088/17426596/1321/2/022099

Murdiyanto, T., \& Mahatama, Y. (2014). Pengembangan Alat Peraga Matematika Untuk Meningkatkan Minat Dan Motivasi Belajar Matematika Siswa Sekolah Dasar. Sarwahita, 11(1), 38. https://doi.org/10.21009/sarwahita.111.07

Prabowo, C. A., \& Widodo, W. (2018). Mengukur
Tingkat Perkembangan Kognitif Siswa Sekolah Dasar dalam Bidang Sains menggunakan Tes Kemampuan Penalaran Ilmiah. Proceedng Biology Education Confrence, 15(2004), 69-73.

Sarjana, K. S., Baidowi, B., Arjudin, A., \& Hapipi, H. (2020). Perancangan Media Peraga dan Pedoman Operasionalnya Kepada Para Guru Sekolah Dasar. Jurnal Pijar Mipa, 15(3), 229. https://doi.org/10.29303/jpm.v15i3.1460

Sarjana, K., Sridana, N., \& Turmuzi, M. (2018). Disain Media Peraga Dan Bantu Pembelajaran Geometri Bagi Siswa Sekolah Dasar Kelas Tinggi. Jurnal Ilmiah Profesi Pendidikan, 3(2), 176-182.

Siagian, M. D. (2017). Pembelajaran Matematika Dalam Persfektif Konstruktivisme. NIZHAMIYAH: Jurnal Pendidikan Islam Dan Teknologi Pendidikan, VII(2), 61-73.

Sudarwanto, S., \& Hadi, I. (2014). Pengembangan Alat Peraga Pembelajaran Matematika Sekolah Dasar Untuk Meningkatkan Kemampuan Berpikir Matematis Siswa. Sarwahita, 11(1), 32. https://doi.org/10.21009/sarwahita.111.06

Sugiarto, Junaedi, I., \& Waluya, S. B. (2012). Pembelajaran Geometri Berbasis Enaktif, Ikonik, Simbolik untuk Menumbuhkembangkan Kemampuan Berpikir Kreatif Peserta Didik Sekolah Dasar. Journal of Primary Educational, 1(1).

Sugrah, N. U. (2020). Implementasi teori belajar konstruktivisme dalam pembelajaran sains. Humanika, 19(2), 121-138. https://doi.org/10.21831/hum.v19i2.29274 